AGRARIS: Journal of Agribusiness and Rural Development Research

Vol. 3 No.2 J uli 2017

\section{Keberanian dalam Mengambil Keputusan dan Risiko oleh Petani Padi Organik Di Kabupaten Bantul}

https://doi.org/10.18196/agr.3253

\section{ABSTRACT}

Entrep reneurship on organic farming is often faced with high risks. This study aims to determine the courage of farmer in decision making and risk taking on organic rice farming and to know the factors that influence it. The research was conducted by survey method. Data were collected through interviews to 116 organic rice farmers in Bantul Regency, then analyzed descriptively and regression analysis. The results showed that the courage of farmers in decision making and risk taking on the organic rice farming is strong enough. Age, training, market orientation and cooperation network have a positive effect on the courage of farmer in decision making; while government support has a negative effect. Meanwhile, the courage of farmer in risk taking on organic rice farming is influenced by market orientation.

Keywords: decision making, entrep reneurship, organic rice farming, risk taking.

\section{INTISARI}

Kew irausahaan pada pertanian organik sering dihadapkan pada risiko usahatani yang tinggi. Penelitian ini bertujuan untuk mengetahui keberanian petani dalam mengambil keputusan dan mengambil risiko usahatani padi organik serta mengetahui faktor-faktor yang mempengaruhinya. Penelitian dilakukan dengan metode survei. Data dikumpulkan melalui wawancara kepada 116 petani padi organik di Kabupaten Bantul, kemudian dianalisis secara deskriptif dan analisis regresi. Hasil penelitian menunjukkan bahwa secara umum keberanian petani dalam mengambil keputusan dan mengambil risiko pada kewirausahaan usahatani padi organik sudah cukup kuat. Umur, pelatihan, orientasi pasar dan jaringan kerjasama berpengaruh positif terhadap keberanian petani dalam pengambilan keputusan; sedangkan dukungan pemerintah berpengaruh negatif. Sementara itu, keberanian pengambilan risiko usahatani padi organik dipengaruhi orientasi pasar.

Kata kunci: kewirausahaan, mengambil keputusan, mengambil risiko, usahatani padi organik.

\section{PENDAHULUAN}

Indonesia merupakan negara agraris yang sebagian besar penduduknya bekerja di sektor pertanian. Namun demikian, sebagian besar petani Indonesia masih dalam kategori miskin dengan tingkat pendapatan yang rendah. Rendahnya pendapatan petani disebabkan oleh skala usahatani yang kecil, bahkan sebagian besar termasuk dalam skala usahatani rumah tangga yang masih bersifat subsisten, dengan pengelolaan usahatani sederhana. $\mathrm{H}$ al demikian akan berdampak pada rendahnya kuantitas dan kualitas produksi yang dihasilkan.

Peningkatan produktivitas dan kualitas produk pertanian antara lain dilakukan melalui pengembangan pertanian organik. Sistem pertanian organik merupakan suatu sistem pertanian holistik yang bertujuan meningkatkan kesehatan agroekosistem termasuk keanekaragaman hayati, siklus biologi, dan 
aktivitas biologi tanah untuk mengoptimalkan produksi tanaman (Budiasa, 2014). Oleh karena itu produk pangan organik selayaknya dihasilkan dari suatu sistem pertanian yang mempertahankan kesehatan tanah, ekosistem dan manusia (USDA, 2010). Di samping itu, secara finansial produk organik memiliki nilai jual yanglebih tinggi dibanding produk dari pertanian konvensional (Stone \& Francis, 2008; H idayat \& Lesmana, 2011).

Di Indonesia, penerapan metode bertani secara organik mulai dikenal pada pertengahan tahun 1980-an yang sebagian besar dipelopori oleh perseorangan dan lembaga non pemerintah (Sulaeman, 2006). Walaupun pemerintah telah mencanangkan berbagai kebijakan dalam pengembangan pertanian organik yaitu 'Go Organic 2010', namun perkembangan pertanian organik di Indonesia masih sangat lambat. Luas areal pertanian organik di Indonesia dari tahun 2007-2010 mengalami peningkatan, namun pada tahun 2011 kembali mengalami penurunan (Tabel 1). Kondisi demikian secara umum terjadi di berbagai wilayah, termasuk di $D$ aerah Istimewa Yogyakarta yang dikenal sebagai wilayah dengan masyarakat petani yang responsif terhadap pembaharuan. Pada tahun 2009, baru sebanyak 3\% dari total 58.000 hektar sawah di Daerah Istimewa Yogyakarta dikelola dengan menerapkan sistem organik.

\section{TAB⿴囗十 1 巴सEMBANCANLUSAFEAPERANANGOANKD INDONEA}

\begin{tabular}{lll}
\hline Nb & Thun & Les(Ha) \\
\hline 1 & 2007 & 40970 \\
2 & 2008 & 208.535 \\
3 & 2009 & 274.985 \\
4 & 2010 & 238.872 \\
5 & 2011 & 235.063 \\
\hline
\end{tabular}

Sumber: SPOI, 2011

Di Daerah Istimewa Yogyakarta, Kabupaten Bantul dikenal sebagai wilayah dengan perkembangan pertanian organik relatif lebih baik. Dari 16.000 hektar lahan padi, sudah $5 \%$ lahan dikelola dengan menerapkan sistem organik, bahkan produk yang dihasilkan beberapa sentra sudah tersertifikasi organik (http:/ / www.trubus-online.co.id). $\mathrm{N}$ amun demikian, jika dilihat dari luasnya lahan sawah yang diusahakan untuk tanaman padi, baru sebagian kecil potensi dikembangkan untuk menangkap peluang pasar padi organik yang masi $\mathrm{h}$ cukup terbuka. $\mathrm{H}$ al ini disebabkan secara umum kemampuan kewirausahaan petani masih rendah, baik dalam kemampuan pemasaran maupun minat dan motivasi dalam mengembangkan pertanian organik.
Pemanfaatan potensi sumberdaya alam pertanian, dalam hal ini lahan, sangat tergantung pada potensi sumberdaya manusia, khususnya petani. Selama ini peran petani sebagai pelaku utama yang memiliki kemampuan kreativitas dan daya cipta kurang dioptimalkan. Keberhasilan petani mencapai kinerja usahatani yang tinggi tidak hanya ditentukan oleh kegiatan teknik budidaya semata, tetapi juga ditentukan oleh kemampuan manajerial petani baik sikap, pengetahuan dan ketrampilan yang diaktualisasikan dalam menjalankan usahataninya, mulai dari persiapan tanam sampai pemasaran produk yang dihasilkan.

Petani berperan sebagai manajer, juru tani dan manusia biasa yang hidup dalam masyarakat (M osher, 1991). Sebagai manajer, petani akan berhadapan dengan berbagai alternatif pilihan dalam mengambil keputusan yang harus dipilih untuk diusahakan termasuk keputusan pilihan teknologi dan alokasi sumberdaya usahataninya. Keberanian dalam mengambil keputusan, merupakan pola pikir kewirausahaan yang akan terbentuk melalui interaksi dalam keluarga. Keberanian dalam mengambil keputusan akan tumbuh dengan baik, ketika petani mendapat dukungan dari lingkungan keluarga (H isrich, Peters, \& Shepherd, 2005).

Keberanian dalam mengambil keputusan dan risiko merupakan bagian dari ciri kewirausahaan. Karakter kewirausahaan merupakan ciri yang melekat pada diri wirausahawan itu sendiri, antara lain motivasi, inovasi dan kreativitas, serta keberanian dalam mengambil keputusan dan mengambil risiko. Salah satu ciri watak wirausaha adalah kemampuan mengambil risiko dan suka pada tantangan (M eredith, Nelson, \& Neck, 1995).

O rang yang memiliki karakter kewirausahaan digambarkan sebagai orangyang mempunyai naluri (semangat, jiwa, nalar, intuisi, dan kompetensi) untuk berbisnis, pengambil resiko, berani memutuskan dengan cepat dan benar (H eflin, 2011); mempunyai ambisi dan motivasi yang kuat (H endro, 2011); memiliki kemampuan mengambil resiko yang wajar dan suka tantangan, keorisinilan inovatif dan kreatif, serta fleksibel (A bidin, 2007). Inovasi, pengambilan risiko, dan proaktif membentuk kontribusi unik terhadap karakter kewirausahaan (Lumpkin \& D ess, 2001). Inovatif, kebutuhan berprestasi, berani mengambil risiko dan percaya diri merupakan beberapa karakter kewirausahaan (Koh, 1996).

Kewirausahaan petani merupakan salah satu faktor yang sangat penting dalam menentukan keberhasilan usaha yang berorientasi pasar (Saragih, 1996). Kelompok yang berorientasi bisnis diharapkan mampu menumbuhkan dan men gembangkan petani inovator dan motivator yang berjiwa wirausaha (H artono, 2003). Semakin tinggi karakter 
kewirausahaan, maka semakin besar kemungkinan seorang individu berkeinginan untuk menjadi pengusaha. Jiwa kewirausahaan petani perlu ditumbuhkan menghadapi tekanan lingkungan pasar yang tidak kondusif (W ibowo, 2005). Penguatan inovasi, keberanian mengambil risiko, kepemimpinan, motivasi berwirausaha, kekompakan, serta kebijakan pemerintah dapat meningkatkan perilaku kewirausahaan (Nursiah, Kusnadi, \& Burhanuddin, 2015).

Keberanian dalam pengambilan keputusan merupakan hal kritis dalam tahap pengembangan usaha. Persiapan bagi keputusan yang efektif untuk waktu yang akan datang seharusnya didasarkan pada antisipasi terhadap perubahan lingkungan (Papalova \& Andrea, 2016). Namun demikian hasil penelitian menunjukkan bahwa para manajer tidak mengetahui faktor lingkungan yang harus dipahami, diuji dan diperkirakan. Penggabungan tiga pendekatan, yaitu faktor kepribadian (kebutuhan akan prestasi dan efikasi diri); faktor lingkungan (seperti akses terhadap modal, informasi dan jaringan sosial); dan faktor demografis (jender, umur, latar belakang pendidikan dan pengalaman bekerja) sebagai faktor penentu semangat kewirausahaan (Indarti, 2004). U mur dan gender wirausahawan signifikan mempengaruhi kinerjabisnis (Ainin, Kamarulzaman, Farinda, \& Azmi, 2010), kemauan seseorang memulai suatu usaha baru, setelah sebelumnya mengalami kegagalan, tergantung pada kemampuannya belajar dari pengalaman (M inniti \& Naude, 2010). Pendidikan berdampak positif terhadap kinerja dan berkontribusi terhadap pertumbuhan usaha ( $M$ at \& Razak, 2011).

Bantuan finansial atau aksesibilitas kredit merupakan faktor lingkungan yang paling penting dalam aktivitas wirausaha (M at \& Razak, 2011). Bagi wirausaha kesenjangan akses terhadap pelatihan dan konsultasi merupakan alasan utama yang selalu digunakan untuk menjelaskan kinerja mereka yang rendah (Roomi \& H arrison, 2008). Skala usaha menjadi salah satu faktor penting bagi proses organisasi dan kinerja (Baum, Locke, \& Smith, 2001). Kurangnya jaringan merupakan hal yang banyak ditemukan sebagai permasalahan dalam kewirausahan (Itani, H anifa, Sidani, \& Imad, 2009). Sementara itu, beberapa kasus kebijakan pengembangan kelompok (cluster development policies) di Indonesia belum berjalan dengan sukses karena terbatasnya dukungan dari pemerintah lokal dan organisasi lainnya (Tambunan, 2005).

Kajian terkait dengan keberanian dalam pengambilan keputusan dan risiko di bidang usaha pertanian, usahatani padi organik, masih belum banyak mendapat perhatian. Studi ini mengkaji keberanian petani dalam mengambil keputusan dan mengambil risiko usaha, dan menganalisis faktor yang menentukannya. M elalui informasi yang disajikan, berbagai pihak yang mempunyai perhatian terhadap pengembangan pertanian organik dapat mengambil langkah strategis untuk memperkuat karakter kewirausahaan, khususnya keberanian dalam mengambil keputusan dan mengambil risiko usaha.

\section{METODE PENELITIAN}

Penelitian dilakukan dengan metode survei pada petani padi organik di sentra pengembangan padi organik di Kabupaten Bantul, yang meliputi Kecamatan Bambanglipuro, Kecamatan Pandak, Kecamatan Imogiri, Kecamatan Pundong dan Kecamatan Srandakan. D ari lima kecamatan terdapat enam desa yang memiliki kelompok tani masih aktif dalam pengembangan usahatani padi organik. $D$ ari masing-masing kelompok tani diambil 20 sampel petani secara acak. Namun, dari 120 petani yang dijadikan responden, hanya 116 responden yang datanya lengkap untuk dianalisis.

Penelitian ini menggunakan sejumlah variabel gabungan, yakni: keberanian mengambil keputusan, keberanian mengambil resiko, akses mendapatkan kredit, pelatihan, orientasi pemasaran, jaringan kerjasama, dan dukungan pemerintah yang diukur dengan skor pada (Lampiran 1). Karakteristik kewirausahaan, yang dilihat dari keberanian mengambil keputusan dan keberanian menanggung risiko dianalisis secara deskriptif, dengan kriteria sebagai berikut.

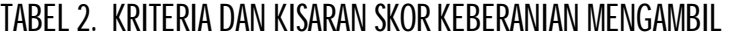 K日UIUSANDANRSKO}

\begin{tabular}{lll}
\hline Nb & Skoridarda & Kiteia \\
\hline 1 & $1,00-2,33$ & Lendh \\
2 & $2,34-3,6$ & Ckpket \\
3 & $3,68-5,00$ & Ket \\
\hline
\end{tabular}

Pengaruh faktor individu dan lingkungan usaha terhadap keberanian mengambil keputusan dan keberanian mengambil risiko dianalisis menggunakan regresi linier. Variabel terikat dalam penelitian ini merupakan data ordinal (skor), sehingga dalam regresi linier digunakan skor normal. Model regresi linier dalam penelitian ini adalah sebagai berikut.

$$
Y_{t}^{*}=\beta_{0}+\beta_{1} X_{1}+\beta_{2} X_{2}+\beta_{3} X_{3}+\cdots+\beta_{9} X_{9}
$$

$Y_{t}^{*}$ adalah skor normal pengambilan keputusan/ skor normal keberanian mengambil risiko, $X_{1}$ adalah akses mendapatkan kredit (skor), $X_{2}$ adalah pelatihan (skor), $X_{3}$ adalah orientasi pemasaran (skor), $X_{4}$ adalah jaringan kerjasama (skor), $X_{5}$ adalah dukungan pemerintah (skor), $X_{6}$ adalah 
TABH 3 SCRK世田ANANFEIAN PAD FCANKDAAMMENGAMELKEUILSAN

\begin{tabular}{|c|c|c|c|c|c|c|c|}
\hline \multirow[t]{2}{*}{ Irdkdor } & & \multicolumn{5}{|l|}{ So } & \multirow{2}{*}{$\begin{array}{l}\text { Peda } \\
\text { Skor }\end{array}$} \\
\hline & & 1 & 2 & 3 & 4 & 5 & \\
\hline \multirow[t]{2}{*}{ DkunganPibad } & junteh(oang) & 1 & 3 & 0 & 97 & 15 & \multirow[t]{2}{*}{4,04} \\
\hline & $\%$ & $0, \&$ & $2,5 C$ & C & 82,76 & $12,9=$ & \\
\hline \multirow[t]{2}{*}{ Dekunganlsti } & junteh (arng) & 1 & 0 & 3 & 76 & 36 & \multirow[t]{2}{*}{4,26} \\
\hline & $\%$ & $0, \notin$ & C & $2,5 \mathrm{C}$ & 6,5 & 31,0 & \\
\hline \multirow[t]{2}{*}{ Dekngenkeluaga } & junteh(oang) & 3 & 0 & 0 & 74 & 39 & \multirow[t]{2}{*}{4,27} \\
\hline & $\%$ & 2,59 & C & C & ๔,, & 33,6 & \\
\hline \multirow[t]{2}{*}{ Dkungenpetar lair } & junteh(arng & 16 & $\pi$ & 1 & $\varepsilon$ & 2 & \multirow[t]{2}{*}{2,15} \\
\hline & $\%$ & 13,79 & 66,38 & 11,27 & 8 & 1,72 & \\
\hline \multirow{2}{*}{$\begin{array}{l}\text { Dekungen kelua } \\
\text { kelonpok }\end{array}$} & junteh (oang) & 16 & 81 & 12 & 7 & 0 & \multirow[t]{2}{*}{2,08} \\
\hline & $\%$ & 13,79 & 69,93 & 10,34 & 608 & 0 & \\
\hline \multicolumn{7}{|c|}{ StorKeberrianMengantil Keptusar } & 3,36 \\
\hline
\end{tabular}

umur (tahun), $X_{7}$ adalah pendidikan (tahun), $X_{8}$ adalah tanggungan keluarga (orang), $X_{9}$ adalah pengalaman (tahun).

\section{HASIL DAN PEMBAHASAN \\ KEBERANIAN MENGAMBIL KEPUTUSAN}

Salah satu karakter kewirausahaan petani padi organik adalah keberanian mengambilan keputusan. Keberanian petani dalam mengambil keputusan merupakan akumulasi dari dukungan pribadi dan dukungan orang di sekitarnya, yaitu istri, keluarga, petani lain dan ketua kelompok. Semakin besar dukungan pribadi dan dukungan lingkungan, maka keberanian petani dalam mengambil risiko semakin kuat; sebaliknya dalam kondisi kurangnya dukungan pribadi dan lingkungan, makakeberanian mengambil keputusan semakin lemah.

Keberanian petani padi organik dalam mengambil keputusan termasuk dalam kategori cukup kuat, dengan ratarata skor sebesar 3,36 dari kisaran skor 1-5 (Tabel 3). Namun jika dicermati setiap indikator, untuk indikator dukungan pribadi, istri dan keluarga termasuk dalam kategori sangat kuat; sedangkan dukungan petani lain dan kelompok termasuk dalam kategori lemah. $\mathrm{H}$ al ini menunjukkan bahwa keberanian petani organik dalam mengambil keputusan mendapat dukungan kuat dari istri dalam keluarga. M ayoritas pengambilan keputusan adopsi inovasi dilakukan oleh suami atau istri (Batoa, Amri, \& Susanto, 2008).

Lemahnya dukungan dari lingkungan sosial (petani lain dan kelompok tani) menyebabkan usahatani padi organik kurang berkembang, yang diindikasikan dari lambatnya peningkatan luas lahan usahatani organik dari tahun ke tahun. Berbagai studi mengungkapkan pentingnya peran kelompok tani dalam pengembangan usahatani padi organik mengingat fungsi kelompok sebagai agen perubahan, yang memudahkan petani yang tergabung dalam kel ompok untuk mendapatkan akses informasi, teknologi dan dukungan kebijakan pemerintah (Kustiyah, Mustadjab, \& Anindita, 2009; Nuryanti \& Swastika 2011; Prihtanti 2013). D engan demikian penting untuk mendapat perhatian pemerintah untuk meningkatkan peran kelompok dalam pengembangan usahatani padi organik. Ketika kelompok menjalankan fungsi fasilitasinya, baik dalam dalam pemasaran, pendampingan teknologi serta implementasi kebijakan, maka akan semakin kuat keberanian petani untuk mengambil keputusan mengusahakan padi organik.

\section{KEBERANIAN MENGAMBIL RESIKO}

Keberanian petani dalam mengambil risiko usahatani padi organik diukur dari tiga indikator, yakni keberanian menanggung risiko, kesiapan menanggung risiko dan kesukaan untuk mencoba. Secara keseluruhan keberanian petani dalam mengambil risiko termasuk dalam kategori kuat (Tabel 4). N amun, jika dilihat per indikator, skor kesukaan mencoba $(3,19)$ jauh lebih rendah dari keberanian $(4,05)$ dan kesiapan $(4,11)$ petani menangung risiko. Dalam arti lain, petani berani dan siap menanggung risiko yang harus dihadapi dalam mengusahakan padi organik, tetapi petani kurangsuka untuk mencoba hal baru. $\mathrm{H}$ al ini menunjukkan bahwa keberanian dan kesiapan petani untuk mengambil 
TA田4 SCRK田RANANMENGAMLRSKO

\begin{tabular}{|c|c|c|c|c|c|c|c|}
\hline \multirow{2}{*}{ Indkdor } & & \multicolumn{5}{|c|}{ Sor } & \multirow{2}{*}{ PeadaSor } \\
\hline & & 1 & 2 & 3 & 4 & 5 & \\
\hline \multirow[t]{2}{*}{ Berai neraggurgreik } & junth & 2 & $C$ & 2 & 94 & $1 \mathcal{1 E}$ & $4,0 \varepsilon$ \\
\hline & $\%$ & 1,72 & c & 1,72 & 81,0: & 155 & \\
\hline \multirow[t]{2}{*}{ Sap nernangurgresik } & $\begin{array}{l}\text { junth } \\
\text { (ard) }\end{array}$ & 2 & C & 1 & $9=$ & $x$ & 4,11 \\
\hline & $\%$ & 1,72 & c & $0, \mathscr{\infty}$ & 29I & $\mathbf{1 , 2}$ & \\
\hline \multirow[t]{2}{*}{ Slk $n$ nencde } & $\begin{array}{l}\text { junth } \\
\text { (arag }\end{array}$ & 12 & 3 & 7 & $5=$ & 1 & $3,1 \mathrm{C}$ \\
\hline & $\%$ & 10,34 & $25, \propto$ & 6,08 & 45E & $\mathbf{1 1 2}$ & \\
\hline PAtardaStorKdearian! & & & & & & & 3,76 \\
\hline
\end{tabular}

risiko belum didukung sikap kreatif dan inovatif petani dalam mengembangkan usahatani padi organik.

\section{GAMBARAN KONDISI KARAKTERISTIK PRIBADI DAN LINGKUNGAN BISNIS PETANI PADI ORGANIK}

Faktor yang mempengaruhi keberanian dalam mengambil keputusan dan keberanian menanggung risiko usahatani padi terdiri dari faktor individu petani dan faktor lingkungan bisnis. Faktor individu terdiri faktor dari dalam diri petani padi organik yaitu umur petani, pengalaman berusahatani padi organik dan pendidikan petani. Faktor lingkungan bisnis merupakan faktor di luar yang berpen garuh terhadap karakter kewirausahaan. Faktor lingkungan bisnis terdiri dari akses untuk mendapatkan modal, syarat mendapatkan modal, frekuensi pelatihan, orientasi pasar, network/ kerjasama dan dukungan pemerintah.

U mur. Petani padi organik rata-rata berumur 55 tahun. Lebih dari $75 \%$ petani berumur lebih dari 47 tahun, dengan komposisi umur yang terbanyak (52\%) berkisar antara 47-60 tahun (Tabel 5). Artinya, petani organik termasuk dalam usia produktif. Dalam kondisi ini, petani memiliki kekuatan fisik dan kematangan mental untuk mengelola usahatani secara kreatif dan inovatif.

Pengalaman. Petani padi organik ratarata sudah memiliki pengalaman dalam mengelola usahatani padi selama 15 tahun, tetapi sebagian besar (42\%) memiliki pengalaman 810 tahun (Tabel 5). $\mathrm{H}$ al ini menunjukkan bahwa petani yang mengelola usahatani organik memiliki pengalaman berusaha yang sudah cukup lama, sehingga kemampuannya dalam mengel ola usahatani padi tidak diragukan lagi .

Tingkat pendidikan petani padi organik bervariasi mulai dari SD, SMP dan SMA, bahkan perguruan tinggi. Sebagian besar petani $(41,38 \%$ ) berpendidikan SM A, bahkan sudah terdapat 2,59 \% petani yang berpendidikan tinggi atau sarjana (Tabel 5). Kondisi ini menunjukkan bahwa tingkat pendidikan petani sudah sangat baik, sehingga memudahkan petani dalam menerima transfer teknologi baru dalam rangka meningkatkan pendapatan petani.

\section{TABH 5. DSTRBS PEIAN PAD ORCANKBEDASAFANKABAKIR PRBAD}

\begin{tabular}{|c|c|c|c|}
\hline $\mathbf{N}$ & Konprerer & $\begin{array}{l}\text { Junted } \\
\text { (oang) }\end{array}$ & $\begin{array}{l}\text { Pesaterf } \\
\text { (\%) }\end{array}$ \\
\hline \multirow[t]{6}{*}{1} & Uhu (tann) & & \\
\hline & 1 C-32 & 2 & 1,72 \\
\hline & $3=-46$ & 2 & 21,5 \\
\hline & $41-6 C$ & 6 & $52,5 \mathrm{C}$ \\
\hline & 6-74 & 25 & 21,55 \\
\hline & $>74$ & 3 & 2,59 \\
\hline \multirow[t]{6}{*}{2} & Pergdanan(tan) & & \\
\hline & $\varepsilon-1 C$ & $4 C$ & 42,24 \\
\hline & 11-1C & ع & 15,5 \\
\hline & $x-2 \varepsilon$ & 2 & 1891 \\
\hline & - -37 & 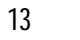 & 11,2 \\
\hline & $>37$ & 14 & 12,07 \\
\hline \multirow[t]{5}{*}{$\Xi$} & Perddlkar & & \\
\hline & I & $4 C$ & $34,4 \varepsilon$ \\
\hline & SMP & 25 & 21,55 \\
\hline & SMF & $4 \epsilon$ & $41, \approx \varepsilon$ \\
\hline & Pा(Sajara) & 3 & $2,5 \mathrm{C}$ \\
\hline
\end{tabular}

Aksesmendapatkan modal. Berdasarkan hasil penelitian hanya $56 \%$ petani yang memanfaatkan kredit atau pinjaman modal. A kses untuk mendapatkan modal yang terdiri dari jarak (skor $=2,08$ ) dan waktu tempuh (skor $=1,92$ ) untuk mendapatkan modal usaha menunjukkan keadaan yang kurang terbuka. Jarak yang harus ditempuh petani untuk mendapatkan kredit kurang lebih $2 \mathrm{~km}$ dengan waktu tempuh 15 menit. Oleh karena itu, masih banyak petani organik (44\%) yang belum memanfaatkan kredit. 
TAEP6 SORAKESMEDAPAIKANMOALDAF LNOKUNGANBSNS

\begin{tabular}{|c|c|c|c|c|c|c|c|}
\hline \multirow{2}{*}{ Irdkdor } & & \multicolumn{5}{|c|}{ Ska } & \multirow{2}{*}{ PedaSka } \\
\hline & & 1 & 2 & $\Xi$ & 4 & 5 & \\
\hline \multirow[t]{2}{*}{ Jacknerceptkankredt } & $\begin{array}{l}\text { Junhtd } \\
\text { (arand) }\end{array}$ & 3 & 66 & $\varepsilon$ & 5 & 7 & $20 E$ \\
\hline & $\%$ & Ž, & 56,9 & 69 & $4,3]$ & $6, \mathbb{E}$ & \\
\hline \multirow[t]{2}{*}{ WAthuterner } & $\begin{array}{l}\text { Juntld } \\
\text { (arng }\end{array}$ & 4 & $\underline{5}$ & $\epsilon$ & $\varepsilon$ & 4 & 192 \\
\hline & $\%$ & 37,07 & 47,41 & 5,17 & 6,90 & 3,45 & \\
\hline
\end{tabular}

TARH 7. SORPEKUBS MENGKUI PEAIIHAN

\begin{tabular}{|c|c|c|c|c|c|c|c|}
\hline \multirow{2}{*}{ Indkdor } & & \multicolumn{5}{|c|}{ Stor } & \multirow{2}{*}{$\begin{array}{l}\text { Peada } \\
\text { Skor }\end{array}$} \\
\hline & & 1 & 2 & 3 & 4 & 5 & \\
\hline \multirow[t]{2}{*}{ Pedaihenpetarianagrik } & $\begin{array}{l}\text { Juntd } \\
\text { (arad) }\end{array}$ & $2=$ & $3=$ & 4 & 3 & 1 & 3,2 \\
\hline & $\%$ & $19, \varepsilon$ & 28,45 & $37, \mathrm{C}$ & $2,5 C$ & 11,2 & \\
\hline \multirow[t]{2}{*}{ Pedtihenpad agarik } & $\begin{array}{l}\text { Juntth } \\
\text { (aring }\end{array}$ & 21 & 41 & 12 & 37 & 5 & 2,69 \\
\hline & $\%$ & 18,1 & 35,3 & 10,3 & 31,9 & 43 & \\
\hline \multirow[t]{2}{*}{ Peddihennmbetpakcrogrik } & $\begin{array}{l}\text { Junthd } \\
\text { (arad) }\end{array}$ & $5 C$ & $3=$ & 2 & 3 & $\subseteq$ & $2,0 E$ \\
\hline & $\%$ & $4 \mathrm{~B}, 1$ & 28,4 & 18,1 & 26 & 7,8 & \\
\hline \multirow[t]{2}{*}{ Peddihannembet dodogrik } & $\begin{array}{l}\text { Junthh } \\
\text { (arang }\end{array}$ & 32 & 43 & 29 & 8 & 4 & 222 \\
\hline & $\%$ & $27,5 \mathrm{C}$ & 37,07 & $\mathbf{Z}$ & 6,9 & 3,4 & \\
\hline
\end{tabular}

Keterangan: Skor 1 (tidak ikut pelatihan), skor 2 (pelatihan 1-3 kali), skor 3 (pelatihan 4-6 kali), skor 4 (pelatihan 7-9 kali) dan skor 5(pelatihan >9 kali)

TAEH 8 SCRORENIAS PASAR

\begin{tabular}{|c|c|c|c|c|c|c|c|}
\hline \multirow{2}{*}{ Indkdor } & & \multicolumn{5}{|c|}{ Sor } & \multirow{2}{*}{ PedaSo } \\
\hline & & 1 & 2 & 3 & 4 & 5 & \\
\hline \multirow[t]{2}{*}{ Dtebesd later } & $\begin{array}{l}\text { Juntd } \\
\text { (oand }\end{array}$ & $5]$ & $5 C$ & $\Xi$ & $\Xi$ & C & 164 \\
\hline & $\%$ & 43,91 & 50,8 & $2,5 \mathrm{C}$ & $2,5 C$ & C & \\
\hline \multirow[t]{2}{*}{ Dijul bertukgatahbesech } & $\begin{array}{l}\text { Junthh } \\
\text { (oang) }\end{array}$ & 33 & 64 & 3 & 15 & 1 & $20 B$ \\
\hline & $\%$ & 28,45 & 55,17 & 2,59 & 12,93 & 0,86 & \\
\hline \multirow[t]{2}{*}{ Dijul bertukgabahkeing } & $\begin{array}{l}\text { Junteh } \\
\text { (oand) }\end{array}$ & 18 & 54 & 6 & 30 & 8 & 262 \\
\hline & $\%$ & 15,52 & 46,55 & 5,17 & 25,86 & 690 & \\
\hline \multirow[t]{2}{*}{ Dijul bettkberes } & $\begin{array}{l}\text { Junteh } \\
\text { (oang) }\end{array}$ & 14 & 7 & 1 & 64 & 30 & 377 \\
\hline & $\%$ & 12,07 & 6,03 & 0,86 & 5耳 & 2586 & \\
\hline \multirow[t]{2}{*}{ Diud bettkberir } & $\begin{array}{l}\text { Juntld } \\
\text { (aand) }\end{array}$ & 3 & $3 x$ & 15 & 27 & 7 & 23 \\
\hline & \% & 30,17 & 32,76 & 12,9 & 27 & $60=$ & \\
\hline
\end{tabular}


TABH 9. SKRJARNGANKBGASANA

\begin{tabular}{|c|c|c|c|c|c|c|c|}
\hline \multirow{2}{*}{ Indkdor } & & \multicolumn{5}{|c|}{ Stor } & \multirow{2}{*}{ PerdaStor } \\
\hline & & 1 & 2 & 3 & 4 & 5 & \\
\hline \multirow{2}{*}{$\begin{array}{l}\text { Frekketenuidergan peryeda } \\
\text { ipt }\end{array}$} & Junted (arang) & $5 C$ & 17 & 24 & 7 & IE & $2,3 x$ \\
\hline & $\%$ & 43,10 & 14,66 & 20,69 & $6,0 B$ & 15,52 & \\
\hline \multirow{2}{*}{$\begin{array}{l}\text { Frekpetemer dergen } \\
\text { keornoktari }\end{array}$} & junted (aang & 6 & 17 & 12 & 5 & 15 & $2, \propto$ \\
\hline & $\%$ & 57,76 & 14,66 & 10,34 & 4,31 & 12,93 & \\
\hline \multirow{2}{*}{$\begin{array}{l}\text { Frekpetemendengen } \\
\text { podsen }\end{array}$} & junted(oang) & 70 & 6 & 12 & 10 & 18 & 2,14 \\
\hline & $\%$ & 60,34 & 5,17 & 10,34 & 8,6 & 15,52 & \\
\hline \multirow{2}{*}{$\begin{array}{l}\text { Keedkdanenesiond dagen } \\
\text { kdorpoktari }\end{array}$} & juntah(arng) & 4 & 4 & 7 & 88 & 13 & 3,88 \\
\hline & $\%$ & 3,45 & 3,45 & $6, ®$ & $\pi, \notin$ & 11,2 & \\
\hline \multirow{2}{*}{$\begin{array}{l}\text { kerangatendenkonitnen } \\
\text { tehadepkdonpoktari }\end{array}$} & junted (aang & $\epsilon$ & $\mathrm{c}$ & $1 \varepsilon$ & 7 & 12 & 3,64 \\
\hline & $\%$ & 5,17 & 7,76 & 15,52 & ๔,乙 & 10,34 & \\
\hline
\end{tabular}

\section{TABH 10 SORDKNGANFEMPNIAH}

\begin{tabular}{|c|c|c|c|c|c|c|c|}
\hline \multirow{2}{*}{ Indkdor } & & \multicolumn{5}{|c|}{ Stor } & \multirow{2}{*}{$\begin{array}{l}\text { Pexta } \\
\text { Stor }\end{array}$} \\
\hline & & 1 & 2 & 3 & 4 & 5 & \\
\hline \multirow[t]{2}{*}{ Adknabartuennod } & Junted & $8 /$ & $\mathrm{C}$ & $C$ & C & $x$ & $2 \propto$ \\
\hline & $\%$ & $\pi$ & C & C & C & $2^{5}$ & \\
\hline \multirow[t]{2}{*}{ Adengapdatiknpertan } & junteh & 100 & 8 & 2 & 2 & 4 & 129 \\
\hline & $\%$ & 8627 & 6,9 & 1,72 & 1,72 & 3,45 & \\
\hline \multirow[t]{2}{*}{ Ackna perbaikaninges } & Junten & 6 & 6 & 15 & ๓ & 28 & 397 \\
\hline & $\%$ & 5,17 & 5,17 & $12, \mathrm{C}$ & 52,59 & 24] & \\
\hline \multirow[t]{2}{*}{ Actnja perbaikanjan } & $\begin{array}{l}\text { Juntth } \\
\text { (orad) }\end{array}$ & 3 & 11 & 2 & ๘ & 39 & 4.05 \\
\hline & $\%$ & 2,59 & 9,48 & 1,72 & 52,59 & 33,2 & \\
\hline \multirow[t]{2}{*}{ Kenodtranzkes pesar } & Junteh & 11 & 30 & 10 & 28 & 37 & 3.43 \\
\hline & $\%$ & $9,4 \varepsilon$ & $25, \propto$ & 8,8 & 24,14 & 31,9 & \\
\hline \multirow[t]{2}{*}{ Kenodkransaratrarspotai } & $\begin{array}{l}\text { Junted } \\
\text { (orad) }\end{array}$ & 12 & $\mathfrak{z}$ & $\epsilon$ & 3 & 34 & 345 \\
\hline & $\%$ & 10,34 & 24,14 & 24,14 & $31,0=$ & 29,31 & \\
\hline
\end{tabular}

Frekuensi mengikuti pelatihan. Frekuensi pelatihan yang diikuti petani organik berkisar antara 1-10 kali untuk pelatihan tentang pertanian organik secara umum; dan berkisar $1-6$ kali untuk pelatihan padi organik, membuat pupuk organik dan membuat pestisida organik. Pelatihan pertanian organik paling sering diselenggarakan, sehingga petani pun lebih sering mengikuti pelatihan ini dibandingkan pelatihan yang lebih khusus. $\mathrm{H}$ al ini ditunjukkan dari skor frekuensi petani mengikuti pelatihan pertanian organik $(3,21)$ yangjauh lebih tinggi dari skor frekuensi mengikuti pelatihan padi organik, pembuatan pupuk dan obat-obatan (Tabel 7). Petani organik mengikuti pelatihan dengan frekuensi ratarata sebanyak 4 kali untuk pertanian organik, 3 kali untuk pelatihan padi organik, dan masing-masing 2 kali untuk pelatihan pembuatan pupuk organik dan pestisida organik.

Orientasi pasar bagi petani padi organik sudah cukup baik, artinya petani sudah berani membuka terobosan baru dalam pemasaran, yaitu menjual padi dalam bentuk beras 
sehingga harganya bisa lebih tinggi dibanding dijual dalam bentuk gabah keringatau basah apalagi ditebaskan di lahan. Tabel 8 menunjukkan bahwa sebagian besar petani tidak setuju $(50,86 \%)$ bahkan sangat tidak setuju $(43,97 \%)$ untuk memasarkan padi organik melalui sistem tebasan; tetapi setuju $(55,17)$ bahkan sangat setuju $(25,86 \%)$ untuk memasarkan dalam bentuk beras.

Jaringan kerjasama. Indikator lingkungan bisnisyanglain adalah jaringan kerjasama bisnis. Sebagian besar petani mempunyai intensitas pertemuan yang relatif rendah, yang ditunjukkan dari rendahnya skor frekuensi pertemuan antara petani dengan penyedia input $(2,36)$; kelompok tani $(2,00)$; dan dengan produsen $(2,14)$ (Tabel 9). Walaupun frekuensi pertemuan antara petani dengan kelompok mendapat skor yang paling rendah, namun petani memiliki kedekatan emosional yang kuat dengan kelompok (skor 3,88); demikian juga dengan kehangatan dan komitmen terhadap kelompok (skor 3,64).

Dukungan pemerintah. Adanya perbaikan jalan merupakan indikator dukungan pemerintah yangmendapat skor paling tinggi $(4,05)$ diikuti dengan adanya perbaikan irigasi $(3,97)$; sedangkan indikator adanya pelatihan $(1,29)$ mendapat skor terendah diikuti indikator adanya bantuan modal $(2,00)$ (Tabel 10). Artinya, dukungan pemerintah yang bersifat fisik, berupa prasarana irigasi, jalan dan pasar sudah banyak dirasakan petani. Sementara dukungan finansial, berupa bantuan modal, hanya dirasakan $25 \%$ petani. D emikian juga dengan dukungan peningkatan keterampil, 87\% petani hanya menapat pelatihan satu kali dalam satu tahun.

PENGARUH FAKTOR INDIVIDU DAN LINGKUNGAN USAHA TERHADAP KEBERANIAN DALAM MENGAMBILAN KEPUTUSAN DAN RISIKO

Keberanian dalam pengambilan keputusan dipengaruhi oleh kondisi individu petani dan lingkungan usaha. Koefisien regresi hasil estimasi faktor yang mempengaruhi keberanian dalam pengambilan keputusan disajikan dalam Tabel 11 .

Kondisi individu petani yang berpengaruh terhadap pengambilan keputusan usahatani padi organik adalah umur petani (Tabel 11). U mur petani berpengaruh positif terhadap pengambilan keputusan usahatani padi organik. Secara umum umur petani masih dalam kondisi produktif dengan rata-rata umur 55 tahun. $\mathrm{H}$ al ini berarti makin tua umur petani dalam masa usia produktif semakin berani men gambil keputusan usahatani padi organik.

Kondisi lingkungan usaha yang berpengaruh terhadap pengambilan keputusan usahatani padi organi adalah pelatihan, orientasi pasar, jaringan kerjasama dan dukungan pemerintah. Pelatihan, orientasi pasar dan jaringan kerjasama berpengaruh nyata secara positif terhadap keberanian pengambilan keputusan. Pelatihan memberikan bekal ketrampilan bagi petani sehingga akan mampu mengambil keputusan. $\mathrm{H}$ al ini sesuai dengan hasil penelitian bahwa pelatihan dan refleksi diri dapat meningkatkan kinerja manajerial termasuk dalam penyelesaian masalah untuk suskes dalam usahanya (D onovan, Guss, \& N aslund, 2015).

\section{TAPIII KOTSENPEGPB FANTRFANTCRYAGMEMPNGAFH PNGAMELANKPUIUSAN}

\begin{tabular}{|c|c|c|c|}
\hline Veriabd & Kofisier & t-hit & $\mathrm{SC}_{\underline{C}}$ \\
\hline Kontate & $-1,40 \mathrm{C}$ & $-1,472$ & $C, 14=$ \\
\hline Uher & 0,016 & $1,58^{* *}$ & 0,117 \\
\hline Perddkar & $-0,0 B C$ & $-1,035$ & $0,30 E$ \\
\hline Kelagge & $-0,08$ & $-1,344$ & 0,18 \\
\hline Penglatar & $-0,012$ & $-1,22 E$ & 0,22 \\
\hline Ase kredt & $-C, O B C$ & $-C, 704$ & C,48: \\
\hline Pedatin & 0,069 & $2,473^{* *}$ & 0,015 \\
\hline Cietai pesar & 0,013 & $2,754^{\text {**** }}$ & 0,007 \\
\hline Jaingenkejæsan & 0,05 & $1,84 C^{*}$ & 0,06 \\
\hline Dekungenreverinta & $-C, O 4 C$ & $-1, \pi 2^{*}$ & $\mathrm{C}, \mathrm{OK}$ \\
\hline \multicolumn{4}{|c|}{$\begin{array}{l}\text { Keterangan: } \\
\text { pada tingkat kesalahan } 1 \% \\
\text { pada tingkat kesalahan } 5 \% \\
\text { bada tingkat kesalahan } 10 \%\end{array}$} \\
\hline
\end{tabular}

O rientasi pasar yang jelas bagi petani membuat petani lebih berani dalam pengambilan keputusan. D emikian juga jaringan kerjasama akan memperkuat keyakinan dalam pengambilan keputusan karena kepercayaan dari mitra usaha yang dijalin. Sementara itu dukungan pemerintah berpengaruh sebaliknya, yakni berpengaruh negatif terhadap pengambilan keputusan usahatani padi organik. $\mathrm{H}$ al ini menunjukkan keberanian petani organik yang kuat seakan tidak memerlukan dukungan pemerintah. Bagi wirausahawan dukungan pemerintah terkadang bisa menimbulkan kecurigaan, sehingga menurunkan keberanian dalam pengambilan keputusan. O leh karena itu perlu komunikasi dan peningkatan hubungan antara petani organik dengan pemerintah, agar petani dan pemerintah dapat saling mendukung program pengembangan pertanian. $\mathrm{H}$ al ini sesuai dengan hasil penelitian yang menyatakan bahwa dukungan pemerintah merupakan salah satu karakteristik sosial ekonomi yang berpengaruh terhadap penentu keputusan investasi oleh investor agribisnis di N igeria Tenggara (N wibo \& Alinbo, 2013).

Pengambilan risiko merupakan suatu unsur kewirausahaan yang sangat penting bagi petani dalam menanggung risiko keuntungan atau kerugian. Manajer akan selalu menghadapi dan sulit menghindari risiko yang semakin 
meningkat dalam penentuan alternatif pilihan usahanya (N aguchi \& Thomas, 2016). Keberanian dalam pengambilan risiko dipengaruhi oleh lingkungan usaha dan kondisi individu petani. Besarnya el astisitas keberanian pengambilan risiko karena pengaruh lingkungan usaha dan kondisi individu dapat dilihat dari koefisien estimasi faktor-faktor yangmempengaruhi keberanian pengambilan risiko disajikan dalam Tabel 12.

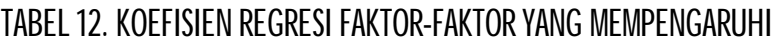 KMBRANANMENCAMBLRSKO}

\begin{tabular}{|c|c|c|c|}
\hline Veriabd & Kofisen & thit & Sg \\
\hline Konstata & $-0,990$ & $-1,058$ & 0,292 \\
\hline Uner & 0,007 & 0,698 & 0,486 \\
\hline Penddlka & $C, O B 2$ & C,981 & $C, 351$ \\
\hline KAluarga & $-0,020$ & $-0,327$ & 0,744 \\
\hline Pengalanan & 0,003 & 0,298 & 0,766 \\
\hline Aseskedt & 0,009 & 0,164 & $0,8 / 0$ \\
\hline Pelatikn & $-0,006$ & $-0,278$ & 0,828 \\
\hline Ointas pesar & 0,096 & $3,681^{* * *}$ & $0, \infty 00$ \\
\hline Jaingønkejæanæ & $-0,037$ & $-1,234$ & 0,220 \\
\hline Dkungenperetintah & $-0,019$ & $-0,710$ & 0,479 \\
\hline
\end{tabular}

Keterangan: *** Signifikan pada tingkat kesalahan $1 \%$

Keberanian pengambilan risiko hanya dipengaruhi secara signifikan oleh lingkungan usaha, yaitu orientasi pasar. O rientasi pasar merupakan kebiasaan petani yang paling efektif untuk memenuhi kebutuhan pelanggan selain itu mendapatkan harga padi organik yang terbaik sehingga bisa meningkatkan nilai tambah dibanding beras non organik. 0 rientasi pasar berpengaruh nyata secara positif terhadap keberanian pengambilan risiko, keberanian dan kesiapan petani untuk mengambil risiko yang didukung sikap kreatif dan inovatif petani dapatmengatasi risiko baik risiko produksi maupun risiko harga. Penjualan padi organik dalam bentuk beras curah atau dalam bentuk kemasan merupakan langkah yang berorientasi pasar dan lebih menjanjikan dalam meningkatkan karakter berwirausaha untuk mengembangkan usahatani padi organik dan meningkatkan pendapatan petani.

\section{KESIMPULAN}

$\mathrm{H}$ asil penelitian menunjukkan bahwa secara umum keberanian petani dalam mengambil keputusan dan risiko sebagai karakter kewirausahaan pada pengelolaan usahatani padi organik cukup kuat. Namun, keberanian petani dalam mengambil keputusan kurang mendapat dukungan kelompok, sehingga perkembangan usahatani padi organik tidak begitu pesat. Keberanian petani dalam mengambil resiko tidak disertai dengan kesukaan petani dalam mencoba sesuatu yang baru. U mur, pelatihan, orientasi pasar dan jaringan kerjasama berpengaruh positif terhadap keberanian petani dalam pengambilan keputusan; sedangkan dukungan pemerintah berpengaruh negatif. Sementara itu, keberanian pengambilan risiko usahatani padi organik hanya dipengaruhi orientasi pasar.

Dalam rangka penguatan kewirausahaan petani padi organik maka pengembangan lingkungan usaha sangat diperlukan berupa pelatihan, kepastian pasar dan jaringan kerjasama dalam kelompok. Dukungan pemerintah dapat dilakukan dengan membangun kepercayaan petani pada pemerintah melalui komunikasi dan pendampingan yang terarah secara intensif dan berkelanjutan.

\section{DAFTAR PUSTAKA}

Abidin, M. (2007). Seri W irausaha yang Tepat. Jakarta: Yayasan Bina Karya Mandiri.

Ainin, S. Kamarulzaman, Y. Farinda, A. G., \& Azmi, A. C. (2010). Business and Entrepreneur Characteristics influence on Business Performance of Professional Small Medium Enterprises. Proceedings of ECIE.The 5th European Conference on Entrepreneurship and Innovation (pp 31). Greece: University of Athens.

Anonim. (2010). Padi Organik Tahan Gempa. http://www.trubusonline.co.id. available online April 2010.

Batoa, H., Amri J. A., \& Susanto, D. (2008) . Faktor-Faktor Yang Berhubungan Dengan Kompetensi Petani Rumput Laut Di Kabupaten Konawe Provinsi Sulawesi Tenggara. Jurnal Penyuluhan, 4(1): 30-38.

Baum, J. R., Locke, E. A., \& Smith, K. G. (2001). A Multidimenssional Model of Venture Growth. Academic Management Journal, 44(2): 292-303.

Budiasa, I. W. (2014). Organic Farming as an Introduction Farmoing System Development toward Sustainable Agriculture in Bali. Asia Journal of Agriculture and Development, 11(1): 66-75.

Donovan, S. J., Guss, C. D., \& Naslund, D. (2015). Improving Dynamic Decision Making Through Training and Self-reflection. Judgment and Decision Making, 10(4): 284-295.

Gatheya, J. W., Bwisa, H. M., \& Kihoro, J. M. (2011). Interaction between Women Entrepreneurs' Age and Education on Business Dynamic in Small and Medium Enterprises in Kenya. International Journal of Business and Social Science, 2(15): 265-272.

Hartono, S. (2013). Pengembangan Bisnis Petani Kecil. dalam Widodo (ed). Peran Agribisnis Usaha Kecil dan Menengah untuk M emperkokoh Ekonomi Nasional. Liberty.

Heflin, F. Z. (2011). Be Enterpreneur. Yogyakarta: Graha IImu. Hendro. (2011). Dasar-Dasar Kewirausahaan. Jakarta: Erlangga.

Hidayat, A. S., \& Lesmana, T. (2011). The Development of rice Organic Farming in Indonesia. RIEBS, 2(1): 1-14

Hisrich, R. D., Peters, M. P., \& Shepherd, D. A. (2005). Entrepreneurship. New York: McGraw-Hill.

Indarti, N., (2004). Factors Affecting Entrepreneurial Intentions among 
Indonesian Students. Jurnal Ekonomi dan Bisnis, 19(1): 57-70.

Itani, Hanifa, Sidani, Y. M. \& Imad Baalbaki. (2011). United Arab Emirates Female Entrepreneurs: Motivations and Frustations. Equality, Diversity and Inclusion. An International Journal, 30(5).

Koh, C., H. (1996). Testing Hypotheses of Entrepreneurial Characteristics: A study of Hong Kong MBA Students. Journal of Managerial Psychology, 11(3): 12-25.

Kustiyah, F., Mustadjab, M., \& Anindita, R. (2009). Analisis Kinerja Program Bantuan Pinjaman di Madura. Jurnal Agro Ekonomi, 27(2): 109134.

Lumpkin, G.T., \& Dess, G.G. (2001). Linking Two Dimensions of Entrepreneurial Orientation to Firm Performance: The Moderating Role of Environment and Industry Life Cycle. Journal of Business Venturing, 16(5): 429-451.

Mat, I. E. N., \& Razak, R. C. (2011). Attributes, Environment Factors and Women Entrepreneurial Activity: A Literature Review. Asian Social Science, 7(9): 124 - 130.

Meredith, G. G., Nelson, R. E., \& Neck, P. A. (1995). Kewirausahaan: Teori dan Praktek (terjemahan). Jakarta: Binaman Pressindo.

Minniti, M., \& Naude, W. (2010). What Do We Know About The Patterns and Determinants of Female Entrepreneurship Across Countries. European Journal of Development Research, 22(3): 277-293.

Mosher, A. T. (1991). Menggerakkan dan Membangun Pertanian: Syaratsyarat Mutlak Pembangunan dan M odernisasi (terjemahan). Jakarta: Yasaguna.

Naguchi, T., \& Hills, T. T. (2016). Experience Based Decision Favor Riskier Alternative in Large Setting. Journal of Behavioral Decision Making, 29(5): 489-498.

Nursiah, T., Kusnadi, N., \& Burhanuddin. (2015). Perilaku Kewirausahaan Pada Usaha Mikro Kecil (UMK) Tempe Di Bogor Jawa Barat. Jurnal Agribisnis Indonesia 3(2): 145-158.

Nuryanti, S., \& K. S. Swastika, D. (2011). Peran Kelompoktani dalam Penerapan Teknologi Pertanian. Forum Penelitian Agro Ekonomi, 29(70): 115-128.

Nwibo, S. U., \& Alinbo, J. O. (2013). Determinant of Investment Decision Among Agribusiness Investor in South-East Nigeria. IOSR. Journal of Business and M anagement, 8(6): 60-67.

Papalova, Z., \& Andrea, G. (2016). Role of Strategic Analysis in Strategic Decision Making. In Procedia Economics and Finance 39 (pp 571579). Rome: 3rd Global Confrence on Business, economics and Finance.

Prihtanti, M.T. (2013). Kinerja dan Multifungsi Sistem Usahatani Padi Organik dan Konvensional. Pasca Sarjana Universitas Gadjah Mada Yogyakarta.

Roomi, M. A., \& Harrison, P. (2008). Training Needs for Women-owned SMEs in England. Education and Training, 50(8/9): 687-696.

Saragih, B. (1996). Peningkatan Keunggulan Daya Saing Agribisnis Memasuki Era Persaingan. Makalah disampaikan pada Seminar Nilai Tambah dalam Peningkatan Daya Saing Agribisnis di Tengah Era Globalisasi, diselenggarakan oleh CGL Communication dan DPP HKTI, Jakarta 25 Juli 1996.

Statistik Pertanian Organik Indonesia. (2011). Aliansi Organis Indonesia. Jakarta

Stone, P. B., Lieblein, G., \& Francis, C. (2008). Potentials for Organik Agriculture to Sustain Livelihoods in Tanzania. International Journal of Agricultural Sustainability, 6(1): 22-36.

Tambunan, T. (2005). Usaha Kecil dan Menengah di Indonesia: Beberapa Isu Penting. Jakarta: Salemba Empat.

Wibowo, R. (2005). State of The Art Ilmu Ekonomi Pertanian Indonesia. Jurnal Agro Ekonomi, edisi Khusus Tahun XXXV, Oktober 2005. 